Казмирчук Вера Евстафьевна, доктор медицинских наук, профессор, директор ТОВ «Институт Иммунологии, Аллергологии и Реабилитации»; 20000, ул. Туровская, 26, Киев, Украина; institut_immunologii@ukr.net; +38 (096) 514- 93-17

ORCID https://orcid.org/0000-0002-9760-4016

\title{
ЗДОРОВЬЕ И ОНКОЛОГИЯ
}

\begin{abstract}
Аннотация
Постановка проблемы. В большинстве публикаций по теме лечения онкопатологии анализируется эффективность операционных вмешательств, химио- и радиотерапии. Но лечение не всегда приводит к желаемому эффекту.

Анализ последних исследований и публикаций. Известно, что ионизирующее излучение, токсические химические вещества, цитостатики (применяются для блокирования развития онкопроцесса), солнечная радиация, а также вещества, обладающие цитотоксической активностью, в сотни и тысячи раз увеличивают вероятность развития опухоли за счет увеличения мутагенеза и угнетения главных механизмов защиты организма активности клеток иммунной системы (натуральных киллеров).

Формулировка цели статьи. Целью данной публикации является ознакомление врачебной аудитории различных специальностей с возможностями лечения онкопатологии, которая считается некурабельной.

Изложение основного материала. За последние 15 лет под нашим наблюдением находилось 27 пациентов в возрасте 20-75 лет, с различной, к моменту обращения «некурабельной» онкопатологией с метастазами, отказом онкоспециалистов от специфической онкотерапии в связи с тяжестью их состояния. У большинства из них первичная опухоль находилась в желудочно-кишечном тракте (15 человек) и была верифицирована как саркома или аденокарцинома.
\end{abstract}


Результаты наших исследований позволяют сформулировать рекомендации по профилактике онкологических заболеваний для лиц из групп повышенного риска их возникновения (например, при наличии генетической предрасположенности, отягощенной наследственности по онкопатологии).

Выводы и перспективы дальнейших исследований. Данные литературы и наблюдения автора свидетельствуют о возможном регрессе опухолевого процесса, в том числе, когда при операции опухоль не была удалена, а лишь констатирована 4я стадия онкопроцесса с дальнейшим полным выздоровлением (время дальнейшего наблюдения пациентов в течение 10-15 лет).

Ключевые слова: здоровье, онкология, иммунитет, загрязненность

\section{Анотація}

Постановка проблеми. У більшості публікацій на тему лікування онкопатології аналізується ефективність операційних втручань, хіміо- та радіотерапії. Однак лікування не завжди призводить до бажаного ефекту.

Аналіз останніх досліджень і публікацій. Відомо, що іонізуюче випромінювання, токсичні хімічні речовини, цитостатики (застосовуються для блокування розвитку онкопроцесу), сонячна радіація, а також речовини, що володіють цитотоксичною активністю, в сотні і тисячі разів збільшують вірогідність розвитку пухлини за рахунок збільшення мутагенезу і гноблення головних механізмів захисту організму - активності клітин імунної системи (натуральних кілерів).

Формулювання мети статті. Метою даної публікації є ознайомлення лікарської аудиторії різних спеціальностей 3 можливостями лікування онкопатології, яка вважається некурабельной.

Виклад основного матеріалу. За останні 15 років під нашим наглядом перебувало 27 пацієнтів у віці 20-75 років, з різною, до моменту звернення «некурабельной» онкопатологією з метастазами, відмовою онкоспеціалістов від специфічної онкотерапіі в зв'язку з тяжкістю їх стану. 
У більшості 3 них первинна пухлина знаходилася в шлунковокишковому тракті (15 осіб) i була верифікована як саркома або аденокарцинома. Результати наших досліджень дозволяють сформулювати рекомендації щодо профілактики онкологічних захворювань для осіб з груп підвищеного ризику їх виникнення (наприклад, при наявності генетичної схильності, обтяженої спадковості по онкопатології).

Висновки та перспективи подальших досліджень. Дані літератури i спостереження автора свідчать про можливе регрес пухлинного процесу, в тому числі, коли при операції пухлина не була видалена, а лише констатовано 4я стадія онкопроцесу с подальшим повним одужанням (час подальшого спостереження пацієнтів протягом 10-15 років).

Ключові слова: здоров'я, онкологія, імунітет, забрудненість

\section{Annotation}

Formulation of the problem. In most publications on the topic of treatment of oncopathology, the effectiveness of surgical interventions, chemo and radiotherapy is analyzed. But treatment does not always lead to the desired effect.

Analysis of recent research and publications. It is known that ionizing radiation, toxic chemicals, cytostatics (used to block the development of the onco process), solar radiation, as well as substances that have cytotoxic activity, hundreds and thousands of times increase the probability of tumor development due to increased mutagenesis and oppression of the main mechanisms of body protection - activity of cells of the immune system (natural killers).

Formulating the purpose of the article. The purpose of this publication is to familiarize the medical audience of different specialties with the possibilities of treating oncopathology, which is considered noncurrency.

Presenting main material. Over the past 15 years, under our supervision, there were 27 patients aged 20-75 years, with different, before the treatment of "non-smoking" oncopathology with metastases, the refusal of oncologists from specific oncotherapy due to the severity of their condition. 
In most of them, the primary tumor was in the gastrointestinal tract (15 people) and was verified as sarcoma or adenocarcinoma. The results of our studies allow us to formulate recommendations for the prevention of cancer for those at high risk of their occurrence (for example, in the presence of genetic predisposition, burdened heredity on oncology pathology).

Conclusions and perspectives of further research. The literature data and observations of the author testify to possible regression of the tumor process, including, when the tumor was not removed during surgery, but only the 4th stage of the oncope process with further complete recovery (the time of follow-up of patients within 10-15 years) was confirmed.

Key words: health, oncology, immunity, contamination

Постановка проблемы. Мифы и реальность лечения онкобольных. В большинстве публикаций по теме лечения онкопатологии анализируется эффективность операционных вмешательств, химио- и радиотерапии. Фармакологический бизнес заинтересован разрабатывать и производить, продвигать для лечения множество химических препаратов. Некоторые из них используются для подавления онкопроцесса, однако данное лечение не всегда приводит к желаемому эффекту (часто не удается остановить онкопроцесс).

Анализ последних исследований и публикаций. Важнейшим элементом противоопухолевой защиты является отсутствие на мутантных клетках одного из элементов генетической принадлежности к клеткам хозяина молекул HLA 1 класса, в результате чего происходит уничтожение «в зародыше» опухолевых клеток без предварительной подготовки [1]. Подобным образом происходит распознавание опухоли Т-цитотоксическими лимфоцитами, однако осуществляется наличием на опухолевых клетках специфических антигенов, по которым опухолевые клетки отличаются от здоровых клеток. Способность Т-цитотоксических лимфоцитов реагировать на опухолевые клетки зависит также от экспрессии (интенсивности) молекул 
HLA 1 класса на клетках хозяина[1]. Известно, что ионизирующее излучение, токсические химические вещества, цитостатики (применяются для блокирования развития онкопроцесса), солнечная радиация и другие факторы в сотни и тысячи раз увеличивают вероятность развития опухоли за счет увеличения мутагенеза.

Указанные факторы, а также вещества, обладающие цитотоксической активностью, угнетают главные механизмы защиты организма-активность клеток иммунной системы, которые стоят на защите от опухолевого процесса-натуральные киллеры.

Человечество в течение многих лет пыталось разгадать причины, приводящие к онкологическому процессу.Учеными подсчитано, что, при относительно благополучном состоянии здоровья, в организме ежесуточно образуются 10 млн мутантных клеток, каждая из которых может развиться в опухоль.

Однако, на основании анализа последних научных публикаций можно сделать вывод, что на самом деле онкология - не приговор, а «звоночек», время задуматься о состоянии здоровья и его восстановлении. Лауреат золотой медали Нобелевского комитета Рем Викторович Петров сказал следующее: «Тот, кто научится лечить иммунодефициты, тот научится лечить рак» [2]. Профессор института онкологии в Бостоне (США) подтверждает наше мнение, что онкопроцесс возникает на крайней степени загрязненности организма, когда иммунная система не справляется со своей функцией иммунного надзора. С позиции физиологии человеческого организма подтверждается гипотеза, что онкопроцесс появляется в связи с крайней степенью зашлакованности организма.

Заболевание любого органа или системы появляется на уровне нарушения его функционального характера. При своевременной помощи организму этот этап обратим. Когда причина функциональных нарушений длительно не выявлена, наступает патологическая компенсация, которая сопровождается нарушением функции смежных органов и систем и ведет к 
накоплению шлаков и токсинов, что в конечном итоге приводит к декомпенсации. В данной ситуации необходима прежде всего дезинтоксикационная терапия и соответствующая коррекция питания, изменения образа жизни.

Появление в организме онкозаболевания, как правило, не сигнализирует о его начале. Однако есть методики определения степени зашлакованности организма. У больных с любой онкопатологией отмечается высокая степень загрязненности организма (токсическая зернистость нейтрофилов/ТЗН, которая достигает 70-80 \% пр и норме до 10\%).

Формулировка цели статьи. Целью данной публикации является знакомство врачебной аудитории различных специальностей с возможностями лечения онкопатологии, которая считается некурабельной и является смертельным приговором, что бытует среди населения и особенно у врачей, как у онкологов, так и незнакомых с этой проблемой.

Изложение основного материала. Результаты наших исследований позволяют сформулировать следующие рекомендации по профилактике онкологических заболеваний для лиц из групп повышенного риска их возникновения (например, при наличии генетической предрасположенности, отягощенной наследственности по онкопатологии):

- Избегать солнечного облучения с 9.00 до 17.00, при котором натуральные киллеры гибнут , защищая организм от солнечной радиации.

- Поддерживать чистоту организма от паразитов, которые есть в изобилии в земле, молочных продуктах, мясе, рыбе и, попадая в организм человека, загрязняют его продуктами своей жизнедеятельности; также следует помнить, что гельминты являются суперантигенами (суперраздражителями иммунной системы), которые блокируют иммунную систему, в результате чего она не может дать адекватный иммунный ответ (не может защитить).

- Bсе сельхозпродукты содержат ядохимикаты, вносимые при обработке полей и огородов, а также нитриты и нитраты, прочие удобрения, 
вредные для организма. Ввиду этого, обработанные по современным технологиям продукты полей нуждаются в вымачивании водой, тщательном вываривании в чуть подсоленной воде, т.е. в обезвреживании. Свежие овощи для сохранения своих свойств могут быть оксигенированы.

- Учитывая изменения климатических условий в Украине (жаркий климат), продукты, содержащие муку, быстрее плесневеют, а при длительном сохранении и употреблении таких продуктов в организме накапливается плесень, которая так же, как и грибы, вызывает интоксикацию. Следует содержать свое жилье в чистоте, сухости, без грибов и плесени, которая содержится в нечищеных кондиционерах, увлажнителях воздуха, емкостях для воды, ваннах, туалетах, погребах и др. местах..

- Учитывая неудовлетворительное качество молочных продуктов в магазинах (срок годности 1 мес.), люди стараются покупать молоко, творог, сметану на рынках, не понимая, что в них могут находиться такие паразиты, как лямблии. В то же время, пастеризация молока для магазинной продажи (подогрев до 60 град) не уничтожает коровьих и человеческих паразитов (лямблий) в молоке и молочных продуктах питания. Появилось большое количество пациентов с лямблиозом (с симптомами патологии печени и поджелудочной железы, т.е. органов, которые являются местом обитания этих паразитов).

- Стрессу, как фактору срыва иммунных механизмов защиты, подвержены все в современном мире. Избежать его достаточно сложно. Однако следует понимать, что необходимо восстановиться как можно быстрее, используя отдых, режим работы, чистые продукты питания, зелень, натуральные витамины, отвар корня солодки и другие фитопрепараты, избегая чрезмерного влияния на организм продуктов современного технопрогресса.

- Мировая наука и практика приводит множество факторов агрессии современного мира ( мобильная сеть, ТВ-воздействие и др.), которые патологически влияют на человеческий организм, повышая мутационные процессы и снижая защиту от опухолей. 
В здоровом теле при здоровом духе мутационные процессы находятся под контролем защитных сил организма (преимущественно натуральных киллеров).

За последние 15 лет под нашим наблюдением находилось 27 пациентов с различной, к моменту обращения «некурабельной» онкопатологией с метастазами, отказом онкоспециалистов от специфической онкотерапии в связи с тяжестью их состояния. Возраст больных варьировал от 20 до 70 лет. У большинства из них первичная опухоль находилась в желудочнокишечном тракте (15 человек) и была верифицирована как саркома или аденокарцинома.

Другие пациенты были: с Сr грудной железы, предстательной железы, раком гортани и легких. Трое пациентов с крайнередной онкопатологией, как то апластическая анемия, В-клеточная лимфома, невринома плечевого сплетения.

Случай 1: жен., 67 лет. Жалобы на боли, кровянисто-слизистые выделения из прямой кишки. При обследовании у проктолога диагностирована низкодифференцированная ткань - аденокарцинома верхнего отдела прямой кишки с метастазами в паховые лимфоузлы (T4N3M1). Прогноз онкологов был пессиместичен, в связи с этим пациентка обратилась к иммунологу. Была проведена санация паразитов на фоне дезинтоксикационной терапии, с дальнейшим проведением успешной иммунотропной терапии. В настоящая время больная здорова. Время наблюдения 10 лет.

Случай 2:жен., 56 лет. Жалобы на одышку, общую слабость, ощущение стеснения в груди. В онкоцентре поставлен диагноз карцинома левого легкого (T4N3M1). При проведении операции удалено левое легкое. Рекомендованная химиотерапия оказалась неэффективной, пациентка выписана домой. В связи с безысходностью пациентка обратилась к иммунологу. При обследовании пациентки выявлен ЭБВ. Была проведена санация паразитов на фоне дезинтоксикационной терапии, с дальнейшим проведением успешной иммунотропной терапии. Время наблюдения 10 лет. 
Случай 3: муж., 55 лет. Жалобы на вздутие кишечника, боли в животе, общую слабость. При обследовании у онколога выявлена $\mathrm{Cr}$ ободочной кишки (T4N3M1). Учитывая неоперабельные метастазы в малом тазу и тяжесть больного, после химиотерапии выписан домой. Пациент обратился за помощью к иммунологу. Была проведена санация паразитов на фоне дезинтоксикационной терапии, с дальнейшим проведением успешной иммунотропной терапии. Время наблюдения 15 лет.

Случай 4: муж., 64 лет. Жалобы на затрудненное мочеиспускание, боли в нижней части живота, общую слабость. Прооперирован в центре онкологии. Выявлена низкодифференцированная ткань - аденокарцинома предстательной железы (T4N3M1). Была проведена санация паразитов на фоне дезинтоксикационной терапии, с дальнейшим проведением успешной иммунотропной терапии. Время наблюдения 15 лет.

Выводы и перспективы дальнейших исследований. Данные литературы и наблюдения автора свидетельствуют о возможном регрессе опухолевого процесса, в том числе, когда при операции опухоль не была удалена, а лишь констатирована 4я стадия онкопроцесса с дальнейшим полным выздоровлением (время дальнейшего наблюдения пациентов в течение 10-15 лет).

Автор выражает благодарность Н.И. Соболь за участие в подготовке материалов статьи.

\section{Список использованных источников}

1. Казмирчук В.Е. Клиническая иммунология и алергология / Казмирчук В.Е., Ковальчук,Л.В., Мальцев Д.В. - К.: Феникс, 2009, С.399-423

2. Доктор. Ру: Научно-практический медицинский журнал.-2008.-№28.C.48-49.

\section{References}

1. Kazmirchuk, V.Ye., Koval'chuk, L.V. Mal'tsev, D.V. (2009) Klinicheskaya immunologiya $i$ alergologiya [Clinical Immunology and Alergology], Feniks, Kyiv, Ukraine.

2. “Doktor. Ru”, Nauchno-prakticheskiy meditsinskiy zhurnal (2008), vol.28, pp.4849. 